The Geneva Papers on Risk and Insurance, 21 (No. 80, July 1996), 360-382

\title{
Environmental Risk Management in Commercial Enterprises
}

\author{
by Dirk Matten*
}

\section{Introduction}

Since the beginning of the 1970s, the environmental impact of commercial, and especially industrial activities, have become increasingly a subject of public concern. The discussion has in the main focused on physical nuisances such as air and water pollution, soil contamination, use of landscape etc. At the end of the 1980s, the focus changed away from the actual contamination caused in specific cases towards becoming more broadly directed at the risks created by commercial activities. Increasingly, it is not the actual but the potential harm which has become the major concern of the public. Consequently, a significant shift towards risk management can be noticed in literature about environmental management. As a first step, the paper focuses on the structure of environmental risk. This entails a detailed analysis of the stakeholders of the firm in an environmental risk perspective. As a second step, some conclusions for appropriate management strategies are drawn from the structure of environmental risk.

\section{The relevance of environmental risk for industrial and business activities}

Our present society might now be characterized by the term «risk society»1. This reflects the idea that we are no longer living in an «industrial society» («Industriegesellschaft»), where the basic aim is expressed as the abolition of material want, achieved by the investment of material «costs», such as labour, resources, environmental quality etc.

In contrast, the «risk society» establishes a context where the accumulation of wealth and security on the one hand is achieved by the «production» of risks on the other, both of

\footnotetext{
* Lehrstuhl für Betriebswirtschaftslehre, insbes. Produktionswirtschaft und Umweltökonomie, Wirtschaftswissenschaftliche Fakultät, Heinrich-Heine-Universität Düsseldorf.

1 «Risikogesellschaft», see Beck, U. (1992a) and Beck, U. (1992b); in a managerial context see Matten, D. (1994) and Matten, D. (1995a).
} 
which are relatively abstract values. The basic problem for society no longer lies in the material destruction of the environment, but in the potential threat caused by our civilisation in general. Examples of this can be seen in potential nuclear catastrophes (such as Chernobyl), potential accidents in large-scale technical production (such as Bhopal), the potential consequences of our energy-intensive lifestyle (such as the destruction of the ozone layer), or potential consequences of scientific innovation and technological progress (such as genetic engineering). ${ }^{2}$

The sources of all these risks are located in the commercial and especially the industrial world. Environmental risk has therefore to be regarded as one of the basic challenges for business life in the coming years. ${ }^{3}$

\section{Industrial emissions as a source of environmental risk}

\subsection{Characteristics of environmental risk}

Most of the characteristics and definitions of risk, especially in the German literature, are based on Knight's distinction between uncertainty and risk and on the exponential relationship between probability and potential damage. This may be very useful for the analysis and quantification of risk but nevertheless is of limited value to a manager who has to cope with the practical implications of risk. The main reason for this is the fact that the probability (as well as the potential damage) of most sources of environmental risk are very difficult to quantify realistically ${ }^{4}$ Furthermore, managers involved with environmental risk do not need to quantify the extent of the risk as such, at least not in the first instance, but rather need to identify, locate and prioritise appropriate containment strategies. ${ }^{5}$

For the purposes of the argument in this text, the term «risk» will be defined as the possibility of a (negative) gap between the achievable goal in practice and the originally planned goal. ${ }^{6}$ The planned goal in environmental management has to be seen as the «standard» level of pollution (and the ensuing damages within the ecological environment of the firm) which is publicly or legally tolerated. If this standard is not realised in practice the term «emission" will be used. Thus, environmental risk can be defined as the risk of an emission. ${ }^{7}$

In the following text, consideration of environmental risk will be addressed solely from the perspective of commercial activities. This implies a dual approach to the issues which arise (Figure 1$).{ }^{8}$ Firstly there is what might be called «ecological risk». This term encompasses the possibility that commercial activities may result in damage to the firm's

\footnotetext{
${ }^{2}$ From a sociologic perspective see Klattenhoff, H. (1994).

${ }^{3}$ See Wagner, G.R. (1992), Janzen, H. (1995), Jauzen, H. (1996) and Shrivastava, P. (1995).

${ }^{4}$ See the discussion in Keppe, H.J.; Weber, M. (1993) and the referred literature.

${ }^{5}$ Similar objections are uttered by Steger, U.; Antes, J. (1991), pp. 40-42, Meffert, H; Kirchgeorg, M. (1993), pp. 154f. as well as Kirchgeorg, M. (1993), p. 127.

${ }^{6}$ See Wagner, G.R.; Matten, D. (1992), pp. 364-366 and the referred literature.

${ }^{7}$ See also Kistner, K.-P.; Steven, M. (1991), p. 1309; Karl, H. (1995).

${ }^{8}$ See Wagner, G.R.; Matten, D. (1992), p. 367.
} 
Figure 1: Components of Environmental Risk

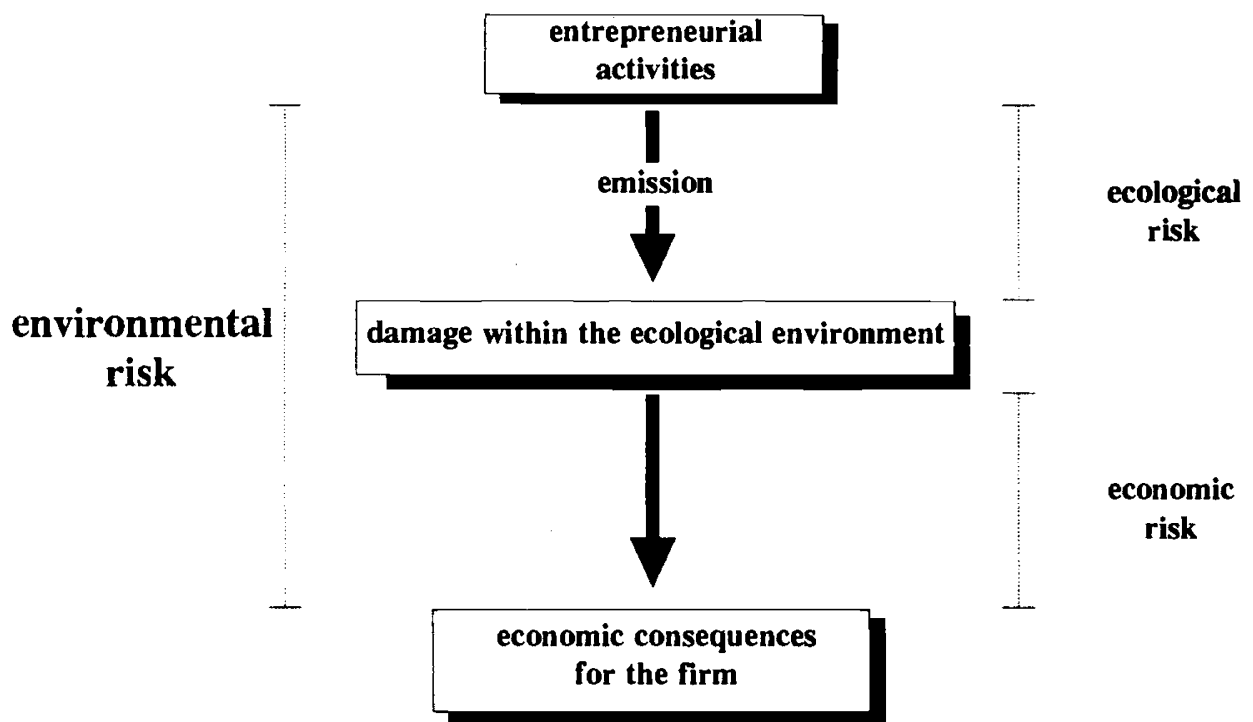

ecological environment above some defined level of tolerance (in other words: it might involve the probability of some kind of emission).

However, it is a fact of experience that firms are not taken to court or fined for all the environmental damage which they cause. Thus, there is a second component to be considered. Environmental risk can be regarded as only relevant if the damage, caused by the firm, might result in economic consequences for that firm. This might be thought of as «economic risk» in this context. This is the basis for the definition of environmental risk above in terms of surmounting an accepted level of pollution. Below this level, the economic consequences are known, but beyond this level, they are uncertain.

Therefore, from the commercial point of view, environmental risk consists of two «sub-risks»: These are the risk of an emission (ecological risk) and the risk that the company will suffer a financial penalty for the damage caused by this emission (economic risk). Thus, environmental risk can be seen as composed of a potential emission with potential economic consequences, represented by the left-hand column of Figure 2, and as a potential economic consequence of an actual emission, shown in the lower part of the right-hand column of Figure 2.

In addition to the above, environmental risks have to be differentiated by another criterion. Risk only exists in the individual's or the group's perception of potential harm. Thus the notion of risk needs to be seen as composed of, on the one hand, an objective assessment of that risk which forms the first category, and, on the other hand, of a perceived (or subjective) assessment which forms the second (upper and lower parts of Figure 2). 


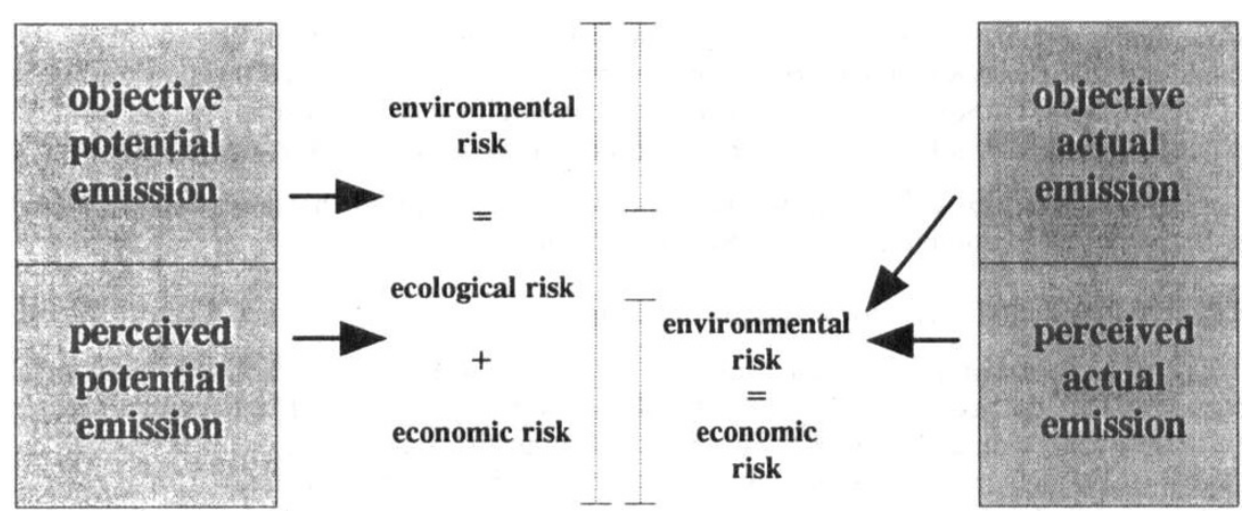

The first category is relevant if the potential emissions leading to these risks exceed an objective level of acceptance such as might be laid down in legislation and governmental acts. The second category describes those risks which exist primarily in the individual's perception or imagination. These latter risks may not be rationally based, but they are nevertheless highly relevant for the acceptance of industrial practice in the eyes of society and especially by those parts of society concerned about the ecological environment. ${ }^{9}$ The risks involved are hard to quantify, and in most cases may also be of very low probability. However the essential is that the potential emissions which are the basis of these perceived risks exceed the level which society is in practice prepared to accept. This may result from a distorted perception of risks involved or because, for a number of reasons, what is considered acceptable by individuals goes beyond simply what is defined by law. This point will be addressed in detail in Section 5 .

\subsection{Environmental risk caused by potential emissions}

Following the above argument, when addressing potential emissions e.g. ecological risk (left part of Figure 2), two kind of emissions must be considered. On the one hand there is the «objective potential emission», which is an emission which, according to an objective assessment of probabilities, may occur or where the potential emission can be measured objectively. Examples of this are incidents in chemical plants or involving road

${ }^{9}$ Haller, M. (1991) and Rohrmann, B. (1990) present a survey over this subject. 
haulage, of which many cases already exist, where standards of pollution set by legislation and regulation have been violated.

On the other hand, there are «perceived potential emissions» which may differ from the first category. In the subjective perception of individuals, the perceived range of possible damages caused within the firm's ecological environment may be broader than the range of those damages which are rationally (objectively) to be expected. ${ }^{10}$ Good examples of these risks are to be found within certain technologies such as nuclear energy, where a potential accident would cause very large consequences yet it has never happened. ${ }^{11,12}$

In addition, this differentiation is based on the assumption that all these ecological risks may cause economic consequences for the firm.

\subsection{Environmental risk caused by actual emissions}

Once an emission has been caused by the firm (which means that the «ecological risk" has already become reality), the consequences may be divided into two categories (the right-hand side of Figure 2 ). Firstly, there is the risk that the emission is objectively identified as such and thus brings with it potential economic consequences. This is the trivial case, called «objective actual emission", in the argument below. The central criterion for objective identification is clearly that the emission can be measured and compared with a standard.

Secondly, it is essential to recognise that not every emission, if indeed any at all, is perceived objectively. ${ }^{13}$ Thus it may be the case that the emission is perceived (subjectively) to be bigger or worse than it is in fact. There might even exist the perception of an emission, which in fact has never occurred at all. An example of this may be seen in the Perrier-case, where the existence of benzene molecules in some bottles led to such a market reaction such that the entire production of the brand had to be removed from sale. These kinds of emissions will be called «perceived actual emissions».

It is obvious that the potential economic consequences of these two kinds of emission - the economic risks involved - may differ vastly from each other. Consequently, both the extent and the type of the environmental risk need to be fully understood in managing risk in practice.

\section{A model of the enterprise from an environmental risk perspective}

The essential relevance of environmental risk for a commercial operation has therefore to be seen in the fact that damage to the ecological environment, which may be caused by its activities, may have undesirable economic consequences for the enterprise. However, these economic damages are not created by «the environment» itself, but by those social groups which are (or feel) harmed by the (actual or potential) emission.

${ }^{10}$ See for example Gethmann, C.F. (1992), pp. 20-25 and the different contributions in Nour Eldin, H. (1989). See also as a broader overview Krimsky, S.; Golding, D. (1992) and The Royal Society (1992).

${ }^{11}$ See the different case studies in Dyllick, T. (1989).

${ }^{12}$ See among others Steger, U.; Antes, J. (1991), pp. 14-17.

${ }^{13}$ See Balderjahn, I.; Mennicken, C. (1995). 


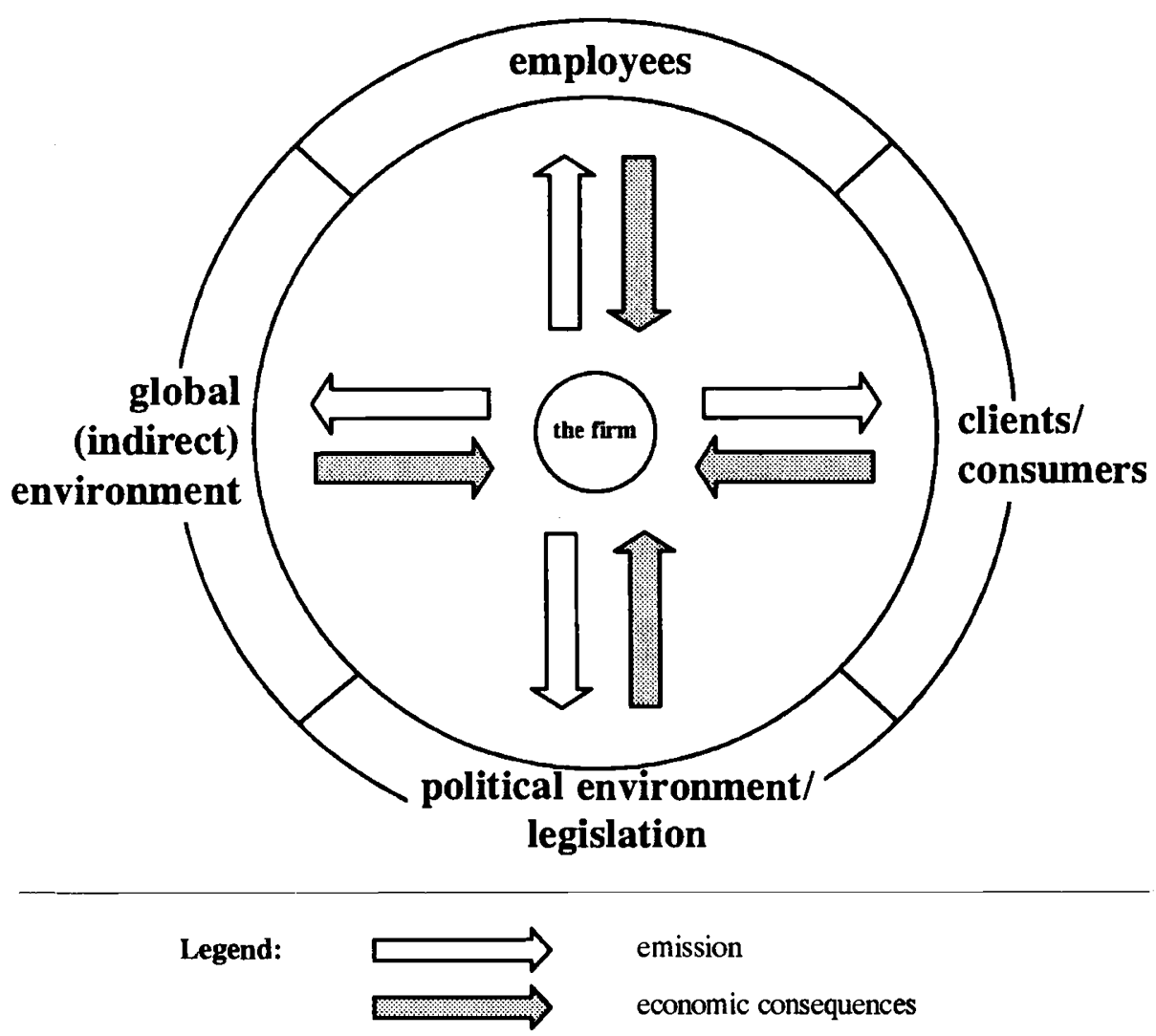

In the growing literature of corporate social responsibility, social groups which may be affected by the activities of a corporation have been collected together under the term «stakeholder».14 This implies that the groups have a «stake», however indirect, in the company. Stakeholders comprise a very wide range of social groups such as employees, customers, suppliers, neighbours, governments and various interest groups representing larger constituencies such as environmental activists etc. This term will be used in this paper in the sense of groups within the broader society which can make some type of claim on the company .

Consideration of the firm's working environment from this perspective leads to the identification of four major «target areas» related to its emissions (Figure 3). For each of

${ }^{14}$ For this concept see Freeman, E.R. (1984). 
these area, there exists a social group which acts as an advocate or a «stakeholder» group. Thus commercial activities may result in emissions within the premises of the enterprise itself where the employees are the group most affected by it. Alternatively an emission may also affect the areas directly surrounding the firm (its micro-environment) and the company's neighbours are the group most affected. In this case, the stakeholders affected by the emission are able to respond by means of their political representatives who may influence the firm in various ways. In this case, the reaction also comes through the political domain, perhaps through legislation and other public (governmental) initiatives. Thirdly, the emission may occur during or after the use of the firm's products. This may create some risk for the firm's clients. Finally, there are emissions which affect the global environment; however, in this case, the source of advocacy, or relevant stakeholder challenging the firm is much more difficult to identify; this will be a matter of further discussion in section 4.3.

The emission (or potential emission) caused by the firm on the one hand and the reaction of the stakeholders concerned with it (the «object» of the emission) on the other can be described in terms of an economic transaction. ${ }^{15}$ In so far as this reaction is unknown or uncertain, the notion of risk is involved. Consequently, the basic aim of environmental risk management - apart from reducing the risk of an emission - is to create institutions which offer a framework for a transaction with stakeholders. Within this framework, the (normally two) partners can agree on the economic compensation which might take place in case of a certain emission (or potential emission). Through the agency of such institutions, the uncertain reaction (the potential economic consequence) of the stakeholder can be transformed into a certain one.

Depending on which type of group is concerned, there are different possible structures and designs for the firm to carry out its transaction with its stakeholders. Though the firm's emissions may affect every stakeholder group equally, each target group of the emission develops an individual pattern of reaction. It can be assumed that the more direct the relation of the firm to the relative group is, the smaller environmental risks will be. Consequently, management of environmental risks requires an identification of the «source group» of the risks in order to apply an appropriate risk management strategy.

\subsection{Employees and consumers as reflectors of environmental risk}

Employees and consumers are directly linked to the firm, and may be regarded having some form of contractual arrangement with it. If there is an emission from the firm, there will be an immediate reaction from these stakeholders and this will be in the context of their existing broader relationship. This may in turn result in formal stipulations in the contract between employee or client and the firm which might be renegotiated in order to balance the exchange.

In this case therefore the response to the emission generally is immediate, and accordingly the environmental risk only exists for a short moment. Normally, there exists an institution between the firm and the affected group, which is either the contract in the case of employees or the market in the case of clients (or even a contract in case of larger clients

\footnotetext{
${ }^{15}$ See Elsner, W. (1987), p. 5 and the referred literature, further Kaas, K.P. (1992b), pp. 3-5.
} 
or projects). Through such mechanisms, customers and employees can react to the environmental risk immediately as part of their contractual relationship with the firm.

If the company is producing for an unknown market, or if there is a chain of dealers between the firm and the final clients or users of the products, the reaction to an emission will not be immediate. Here the contract cannot serve as the basis of transaction between the firm and its stakeholders, because it does not link the firm directly with the customer. Thus, the reaction to an emission may well remain vague, which implies in turn that environmental risk is increased. ${ }^{16}$

\subsection{Legislation as transmitter of environmental risk}

If the firm's emission affects the micro environment of the firm, people who are neither employees nor clients of the firm will try to use their influence through political processes (e.g. making the issue an electoral one or by more general lobbying activities) to give vent to their views. ${ }^{17}$ The relation between the firm and the political institutions in a town/region is a direct one and can also be described as some sort of institutional «contract». On the one side, there are the emissions of the firm. On the other side, national and local government can respond to the emissions through legislation, through specific levies or taxes, or other administrative (regulatory) instruments, and thereby produce a reaction from the group affected by the emission into the enterprise. However, since the reaction and its economic consequences are uncertain, environmental risk occurs.

If the emission of the firm has a national or global impact, people will seek to influence the firm's behaviour via national or even international governmental institutions - an example of this being the Earth - Summit in Rio in 1992. For several reasons, the reaction of national governmental institutions to environmental issues is far more uncertain. Thus, environmental risk which involves processes at this level is very high.

\subsection{Social pressure groups as organizers of environmental risk}

It is possible to envisage situations possible where people are affected by the firm's emissions have no direct relationship to the firm. There is accordingly no direct institution (contract) to react to the emission and to claim some kind of compensation. In this case, people articulate their claims via the national government (as discussed above) or they choose the more direct way of founding and supporting pressure groups to mandate their demands. These may be consumer-action groups, environmental groups etc. The function of these groups is to organize and coordinate the determination of people to take action against the firm's emission. Thus, they can be seen not as the source but the channel by which environmental risks are organized and transmitted. ${ }^{18}$

${ }^{16}$ See Kaas, K.P. (1993), pp. 31-33 and Kaas, K.P. (1994), further Meffert, H; Kirchgeorg, M. (1993), pp. 89-96, but relativating Wimmer, F. (1993), pp. 72-76. See generally to the field of transaction risks Jung, M.; Spremann, K. (1989), especially pp. $94 \mathrm{f}$.

${ }^{17}$ For the management of environmental risks from a political point of view see the article of Biedenkopf, K. in Nour Eldin, H. (1989). The role of approving authorities and public services is described detailed by Knödgen, G. (1992) and Jänicke, M. (1995).

${ }^{18}$ See Bode, T. (1992) and Mulhall, D. (1992). 
These institutions are primarily concerned with impacts on the global or indirect environment of the firm. They may, however, also take on the function of acting on behalf of clients or other stakeholders where there is no alternative institution which provides the framework whereby the transaction «risk vs. economic consequence» can be balanced.

\section{Public acceptance as chief parameter of action for the management of environmental risk}

As mentioned above in a different context, environmental risk occurs when people no longer accept the firm's behaviour towards the natural environment. As soon as the firm's behaviour goes beyond what the public is prepared to accept, some type of reaction from the group which is put at risk, may be expected. Since that reaction generally is not known beforehand, environmental risk is very unpredictable and unbounded. Thus, public acceptance is the central parameter of action for the firm's environmental risk management. ${ }^{19}$

There has been some controversy in the literature about the nature and definition of acceptability. This paper suggests a dual concept. On the one hand, there is a certain public acceptance which is exemplified in actual legislation and standards set by governmental authorities. This is an objective measure of emissions as defined above. On the other hand, in post-industrial societies, it is frequently the case that acceptability in many cases cannot be defined by means of such an objective standard. Many risks, which according to public statements of governmental institutions are said to be acceptable, are not accepted as such by society or special interest groups within society.

The question whether a risk may be regarded as acceptable by people depends upon many other factors, such as individual's perception, personal experience, geographic distance, and psychological and social factors etc. ${ }^{20}$ It would be an oversimplification to categorize these elements under the notion of an «acceptability function». It is more appropriate to consider the main factors which affect the acceptability of perceived risks to be, at a minimum, the (perceived) competence of the firm to handle a certain technology and the trust of the public in the seriousness which that firm attaches to compliance with their public statements. The concept of dual acceptance in this paper is therefore based on the concept of a distinction between «objective» and «perceived» risks as argued above. ${ }^{21}$

Finally, in this paper, an «emission» is said to have occurred if the firm's level of pollution exceeds the level of what is publicly accepted. If public acceptance remains constant in a given period, it follows that an emission can only be the result of the firm's activities. However, account must be taken of the fact that public acceptance does not remain constant over time. Consequently, an «emission» may also occur if the firm does not take proper account of change in public attitudes, most notably if this change is in the direction of reduced acceptability. ${ }^{22}$

${ }^{19}$ Wagner, G.R. (1991) and Hammann, P. (1995).

${ }^{20}$ See the empirical research project in Burgemeister, J.; Weber, M. (1993); see also Balderjahn, I; Mennicken, C. (1995).

${ }^{21}$ Gethmann, C.F. (1992), pp. 17-25. (1995)

22 Wagner, G.R. (1991), pp. 140-142; a current example is discussed by Wagner, G.R.; Matten, D. 


\section{Strategies for the management of environmental risk}

The unique structure of environmental risk should be the starting point for strategies of risk management. Consequently, environmental risk management basically has two objectives: Firstly, the avoidance of emissions or at least the containment of any incidents which might occur. Secondly, the management of the potential reaction of the different stakeholders of the enterprise once an emission has taken place. Here, the structure of the stakeholder group and their pattern of behaviour (as discussed in Chapter 3) are the crucial parameters. The first objective entails the consideration of ecological risk, the second economic risk. Accordingly, environmental risk management has to follow the structure of environmental risk as stated in section 3 exactly. An overview of the subject is given in Figure 4. Generally, the key issue in environmental risk management is the fact that it has to follow those two dimensions «potential/actual emissions» and «objective/perceived emissions» (see again Figure 2).

\subsection{Emission-oriented strategies}

Emission-oriented strategies of risk management are part of the more general risk management activities of the firm. From this perspective, risk management has two broad goals. Firstly, the risk of emissions has to be controlled because emissions may be the result of inefficient economic behaviour. Since we can assume that the firm's plans are geared to a certain, tolerated level of pollution, every emission has to be seen as a failure of management in realizing its plans. Furthermore, all plans should be aimed at achieving the economically optimum allocation of resources in the firm so that any deviation from such plans represent a waste of resources and, thus, extra costs for the business. ${ }^{23}$ Secondly, the

Figure 4: Strategies for the management of environmental risk

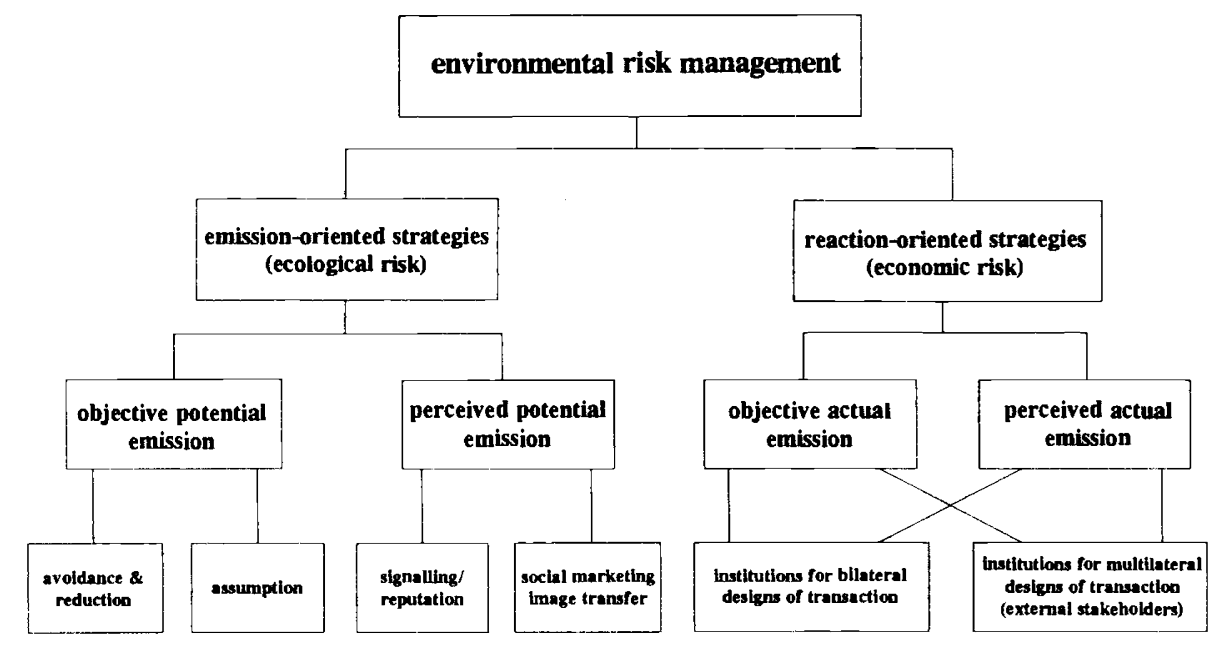

23 An analogous statement is expressed by Kloepfer, who proposes the integration of environmental protection within the firm's quality control system. See Kloepfer, M. (1993), pp. 1129f. 
risk of emissions may be the basis of economic sanctions and, thus, indirectly a source of further costs for the firm (economic risk).

Environmental risk management in this respect has to be separated into two «domains». The first of these domains lies within the premises of the firm itself. This is the area, where hazardous production takes place, for example where research involving some form of risk is done etc. This is therefore the location of a potential emission. The second domain consists of the social environment of the firm, where all emissions are recognized and, as we will assume, consequently assigned to the firm. Here, the firm's task can be seen as an extension of the familiar marketing tools which it might have used for some time. ${ }^{24}$

\subsubsection{Management of the potential emission itself}

Managing the risk of an emission needs to be considered from two perspectives. There are risks which can be prevented or minimized. However, there are also other risks which cannot be transferred or reduced and which are a necessary part of the commercial activities of the firm. An example of this latter instance might be companies dealing with environmental affairs, such as waste management, as a core part of their business. These firms exist because they take over the risks of others and therefore automatically raise the issue of the management of risks to a major strategic issue.

\subsubsection{Avoidance and reduction of environmental risk}

In most instances, the first step in approaching environmental risk management is to start within the firm itself and try to minimise the risks there. This involves risk analysis 25 which does not differ in principle from risk management in any other field in which the firm is involved ${ }^{26}$ Once identification and analysis of risks has taken place, many of those risks can be avoided. This strategy therefore focuses on the sources of risks and their avoidance.

There are numerous strategies and measures which can be applied in order to avoid or reduce risk: ${ }^{27}$

- Elimination of the hazardous product or process and replace them by one which does not bring with it the same environmental risk

- Elimination of hazardous raw materials (asbestos, CFCs etc.)

- Obligation for suppliers to take back all waste (packaging material)

- Segmentation of the production into areas of high and low risk activities (such as waste management)

${ }^{24}$ A survey over possible strategies in environmental risk management can be found in Steger, U.; Antes, J. (1991), p. 22, Janzen, H. (1995), Matten, D (1995b), and Janzen, H.; Matten, D. (1995).

${ }^{25}$ Generally to the subject of risk analysis comp. Renn, O.; Kals, J. (1990), pp. 61-71, Haller, M. (1991), pp. 176f., Gasser, V. (1992), pp. 111f. as well as the practical proposals of Hoffmann, K. (1985), pp. 43-137. (1991).

${ }^{26}$ See as a survey the different papers in Jacob, H. (1986), further Schuy, A. (1989); Mensch, G.

${ }^{27}$ For details see Matten, D. (1994), Janzen, H. (1995), and with empirical cases Matten, D. (1995a). 
- Shutting down or giving up production (partially or totally)

- Dislocation of hazardous production

- Transferring risks to third parties (e.g. logistics, waste management)

- Sealing off a specific process from the surrounding world (e.g. nuclear power stations)

- Design of the use of toxic substances as a closed circular flow

- Integrated pollution control («Integrierter Umweltschutz»)

- Management System: environmental information systems, early detections systems, regular environmental audits, product line-analysis, environment impact assessments, technology assessment, internal production control systems, raising standards, increasing the frequency and scope of supervision and control, build in the notion of «fail-safe» operation

\subsubsection{Assumption of environmental risk}

There are two major categories of activity where the management of considerable risk is a necessary and intrinsic part of the processes used by the firm. Firstly there are those cases where production is inevitably geared to substantial environmental risks, such as large-scale chemical production, energy production (nuclear and conventional), certain traffic systems etc. Secondly there are considerable business opportunities for entrepreneurs willing to take over environmental risks from third parties. Examples of this are waste-management-companies, or forwarding agents who are specialized to take over exactly those jobs which are too risky for other companies. The market for this type of risk management is a growing rapidly and handling of environmental risks in his way has become the core activity of many companies. ${ }^{28}$ tems: ${ }^{29}$

The main focus lies on the management system, especially the following sub-sys-

- Organization: avoid ambiguities as they may occur in matrix-organisations or dottedline-organisations

- Information: efficient and complete internal information and documentation systems

- Controlling: constant observation and control of risks at all stages of the project life cycle; regular accounts (if the risks are quantifiable in this form) or - as will be mostly the case - a qualitative audit

- Personnel: selection, training, motivation, and observation of personal; efficient supervision systems to cope with selection, training and maintenance of performance.

\subsubsection{Management of the perceived potential emission}

As noted above, different social groups or stakeholders do not perceive the firm's risks objectively. In principle two cases are possible; the trivial one where risks are percei-

${ }^{28}$ Beck, U. (1992b), p. 120. (1995a)

${ }^{29}$ For details see Matten, D. (1994), Janzen, H. (1995), and with empirical cases Matten, D. 
ved to be lower than they are in reality, and the other one where risks are perceived to be worse than they really are. In either case, this is generally the result of a lack of complete information which in turn is partly the consequence of the complexity of technical processes. There are several reasons for this phenomenum. The most important might be a lack of understanding of the nature of technical processes, technical statements which in themselves are difficult for laypeople to understand, the limited credibility of statements about hazardous production technologies and, finally that most technical solutions appear inadequate to cope with the sheer quantity of unsolved problems..$^{30}$

It is common practice for companies to engage in specific promotional activities designed to develop public acceptance of its products and create a positive image (or brand identity) for them. However, when environmental risk is included in this, the focus lies no longer solely on gaining acceptance for the products, but on getting acceptance for the production as well. Thus business leaders do not only sell a product to their clients; they may also be regarded as «selling» a way of production, not only to clients but to every social group (or stakeholder) affected by the emission. Since the risk of an emission is inevitably linked to the production process, the potential of an emission has to be «sold» to the public, too.

Instruments and strategies in this context are signalling, contingent contracts, reputation, transference of image between businesses and activities etc. ${ }^{31}$

\subsection{Reaction-oriented strategies}

Once an (objective or perceived) emission has taken place, the firm has to face economic consequences in the form of possible sanctions. Initially, this reaction is uncertain. It may be possible to judge that in some situations, a higher probability of fine or other penalty may occur than in others, but generally the reaction is not predictable. In other words, economic risk exists alongside the environmental risk.

The strategic goal of risk management in this field is to establish mechanisms or institutions whereby the uncertainty of the reactions of the affected social groups can be transformed into a certainty. These institutions therefore act to regulate the transaction between the firm and the affected partner, as noted in section 4.1 .

Figure 5 shows some simple examples for the kinds of institutions involved. In the firm's relation to its employees, the classical institution for the transaction is the employment contract. If there is a job to be done which involves hazard to health (emission), the employee will ask for extra payment as compensation (economic consequence). Since everything is stipulated in the contract, there is no risk for the firm. There is a directly analogous position regulating the firm's relationships with its clients.

Another example is the relationship with the political domain. Here the transaction (emission versus corresponding reaction such as raising of taxes or the lowering of accepted emission standards etc.) is controlled by political institutions such as regulatory authorities.

30 Hammann, P. (1992), p. 138.

31 For details see Kaas, K.-P. (1993), Matten, D. (1994), Janzen, H. (1995), and with empirical cases Matten, D. (1995a) 


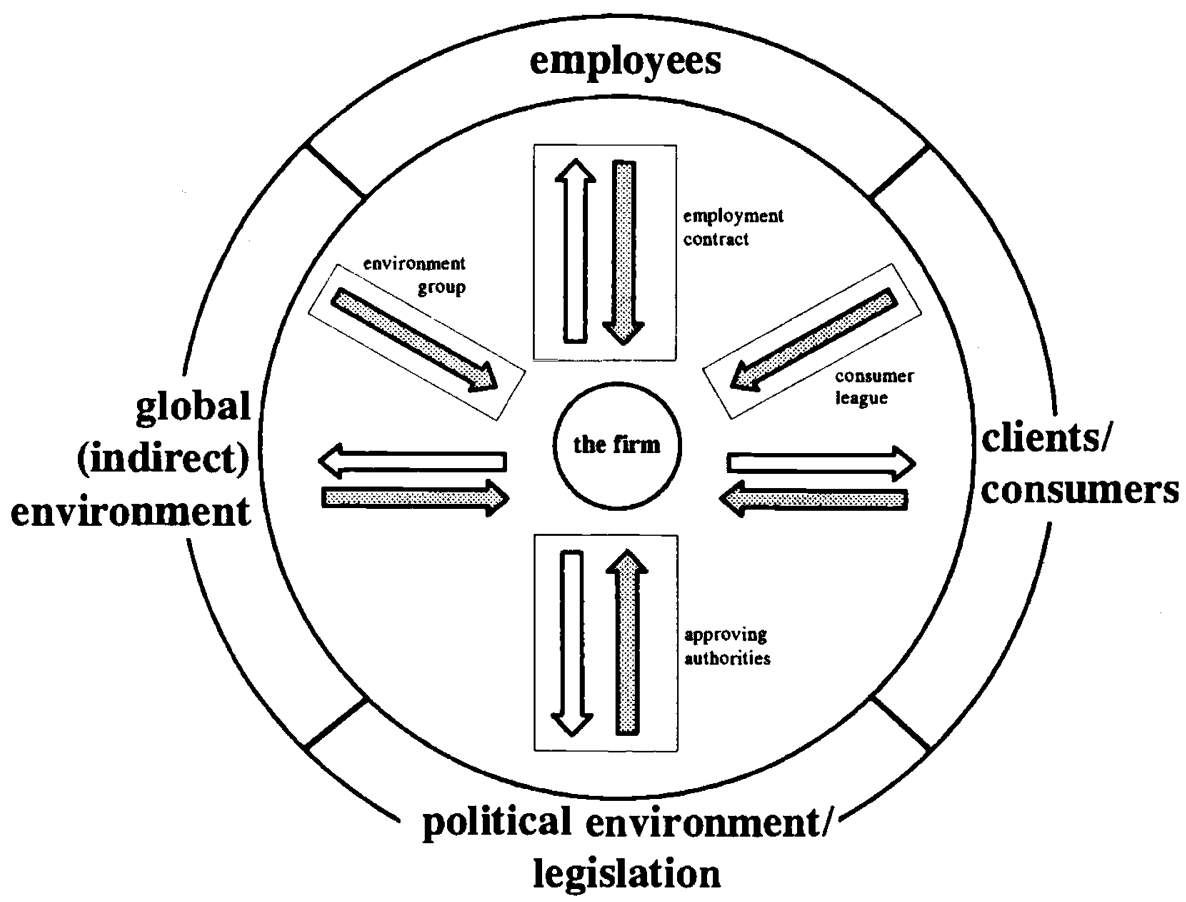

There are however numerous cases where initially no institution of the above mentioned kind exists for the particular stakeholder who is involved. Examples of this were noted in sections 4.2 to 4.4 . All these cases have in common that the economic claims placed on the company are articulated by institutions which have no direct prior relationship of exchange with the firm. Consequently, these institutions cannot serve as an existing framework for a transaction and, thus, as an instrument of risk-reduction. Figure 5 shows consumer-leagues and environmental groups as examples. In the following discussion possible innovative institutions will be considered which might form the basis for possible transactions in these cases.

A further general remark seems to be necessary: the aim of any cooperation between the two parties in the context of environmental risk requires the reduction of an asymmetric distribution of information between the partners: the firm wants to know (and influence) the reaction of the social groups and the social group wants to know (and influence) the risks caused by the firm. Since the starting point is one of secrecy and fear of disclosure, an adequate basis for cooperation must involve a specific commitment to and conscious strategy of revelation. This has a vital consequence to the following arguments. All the institutions which might be proposed to act as intermediary between a company 


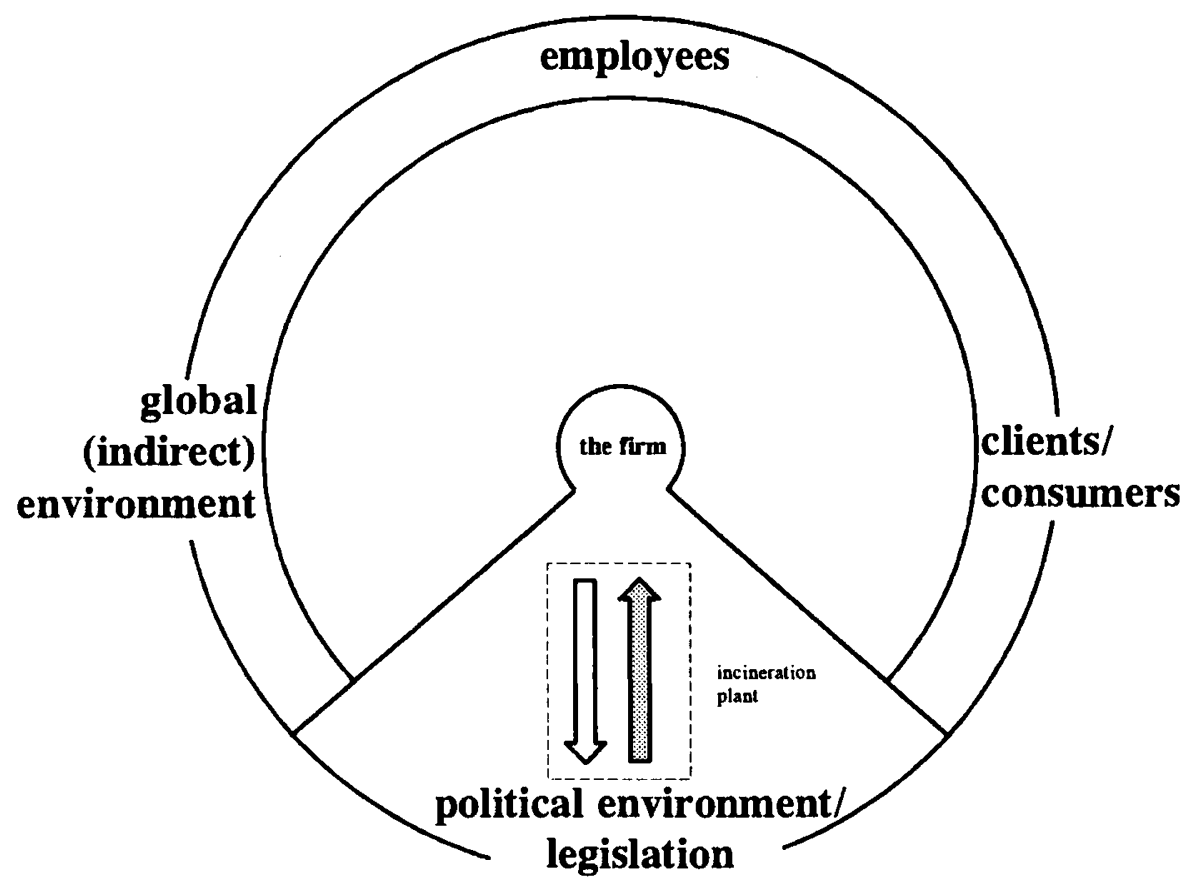

and its stakeholders which do not otherwise have a transactional relationship to it, can only function if the two parties act honestly in sharing relevant information. ${ }^{32}$

\subsubsection{Institutions for bilateral designs of transaction}

(a) Integration

The first possibility for institutions which manage the transactions between a company and its «other» stakeholders is in fact an institution which actually «does away» with the notion of a separateness between the stakeholders and the firm. ${ }^{33}$ In this case, the boundaries of the institution «firm» are extended in such a way that the stakeholder of the enterprise is integrated into the firm. In doing this, the firm does not cling onto the notion of contract as the basis of transaction design but it tries to provide such basis through its own hierarchy. An example of this approach can be found in the traditional mining business. ${ }^{34}$ Here, employees were integrated into the firm by means of houses that were built

${ }^{32}$ Spremann, K. (1990), pp. 567f.

${ }^{33}$ Williamson, O.E. (1990), pp. 85-89.

${ }^{34}$ Williamson, O.E. (1990), pp. 40-44. 
and owned by the mine itself - so-called «tied-houses». The job of the miners was a risky one with severe impacts on their health. However, the potential reactions of the employees (miners) towards that risk could be easily controlled: by means of hierarchy - since they were made part of the enterprise - the firm had an easy institutional framework in order to cope with that kind of transaction. The only element of risk would lie in the possibility that an employee might leave the company totally. However, this was an unlikely event in most cases. In using this example, no justification of the misuse and exploitation of workers in early industrial times is intended; it is simply used as a powerful example of this institutional design.

The construction and subsequent use of an incineration plant is another example of integration and it is possible to model it in a similar way. There are cases where a private company and the political authorities of a certain area together build an incineration plant, an industrial project which normally is perceived as hazardous (Figure 5). As the major source of risk, potential economic sanctions which might arise from the possible emissions of the firm are now integrated into the institution of the «firm», the problem of environmental risk can be regarded as solved. This strategy can only be used directly in a small number of cases, but nevertheless the underlying pattern can be transferred to many other situations. The basic approach is to open the boundaries of the firm and integrate within it those parties which may be the source of environmental risk.

Another example of this general type is the integration of environmental groups such as Greenpeace into the research and development processes of the company in order to anticipate and thereby cope with potential reactions of these groups to the end products of those processes. As soon as these groups are integrated into the firm's processes, the economic consequences which might arise from objections to the potential emissions of the new product, can be discounted in advance and, in effect, the risks can be avoided.

\section{(b) Corporate dialogue}

Another institutional device which can be used to build bridges between a company and its external stakeholders is a «corporate dialogue». 35 Through this device the firm's relationship to the global environment or the firm's relationship to its consumers can be addressed. A similar institutional device of this type is a «consensus conference» which is similar to corporate dialogue and therefore included in the same considerations below. ${ }^{36}$

The underlying philosophy behind thesè devices is that the firm gets in contact with relevant institutions such as consumer-leagues or environmental groups in order to get to know their opinions and understand their reactions to certain activities of the firm. In the sense of this paper, these conferences may serve as a platform where the company can see how the risks of the firm are perceived and what may be the potential reactions to them. A predominant role of these conferences lies is the transfer of information since risk perception is vitally dependant on the level of information. These conferences serve to reduce the perceived potential emissions of the firm and consequently serve to reduce the potential

35 Steinmann, H.; Zerfaß, A. (1993); Steinmann, H.; Zerfaß, A. (1995); furthermore see Wiedemann, P.M. (1990) and Kasperson, R.E.; Stallen, P.J.M. (1991).

36 Weale, A. (1992), pp. 42 f see further on Renn, O. et al. (1995). 
consequences also. This device has already been used in healthcare industry to considerable benefit. ${ }^{37}$

\section{(c) Bargaining solutions}

In a closely similar way, so-called «bargaining conferences» about environmental standards represent another institution which serves to reduce risk for the firm..$^{38}$ In these conferences representatives of industry, politics and environmental groups sit down together to discuss the level and the structure of environmental standards. In this way environmental standards are not an exogenous given variable for the firm, which develop independently and therefore represent a special risk for the firm, but the standards become a parameter which may be influenced and modelled by the firm. The firm itself is directly involved in agreeing the standards.

It is possible that the integration of environment groups and political parties which stand for tight environmental standards may result in standards becoming a little higher than they would be without these conferences. However in the context of risk-reduction, many firms prefer to have higher standards which they know about in advance and are sure about, than to have lower standards with the uncertainty of not knowing when and how they might change in the future. These bargaining conferences have been used for instance in Canada when governmental and industrial institutions needed to establish new standards for NOX - and VOC - emissions.

(d) Informal discussion/policy dialogue

A softer design of institution to regulate transactions with external stakeholders is based on informal discussions and policy dialogue. ${ }^{39}$ Here the major aim is to create a platform where different parties of society may get to know each other and work up a basis of trust. The instrument of informal discussion has been used in Great Britain in form of the National Radiological Protection Board (NRPB) during the 1980s concerning the future of nuclear power. Conferences of this type may serve as an instrument, albeit a very soft and indirect instrument, to increase the predicability for the firm of the reactions of the social groups surrounding it, to its activities and thereby reduce environmental risk.

Policy dialogues, another institutional form, are less specific and act to anticipate directions which a society might take. In these conferences political, industrial, and environmental groups meet to try to form a consensus in their views surrounding a particular policy issue. Part of their task is to test whether such consensus is possible at all. This institutional form has been used in the United States in the shape of the National Coal Policy Project. It is difficult to say whether that project really was a success. However it did provide a forum whereby the opinions and potential reactions of more than 200 social interest groups to the question of whether the use of coal for energy production should be carried on or not, could be compared and contrasted.

\footnotetext{
${ }^{37}$ Steinmann, H.; Zerfaß, A. (1993), pp.9f. and the refferred literature.

${ }^{38}$ Weale, A. (1992), pp. $38 f$.

${ }^{39}$ Weale, A. (1992), pp. 40-42; Renn, O. et al. (1995).
} 
All the instruments and institutional devices described in this section need to be used pro-actively if they are to be really effective in building a constructive dialogue between a company and its stakeholders.

\subsubsection{Institutions for transactions with external stakeholders}

In some cases the institutional process of mediation between a company and its external stakeholders to manage the acceptability of environmental risk, requires the catalysis of some third party. This may be needed because the parties distrust each other or because the problems involved are in fact too complex to be solved by either party, separately or together, or where the mediation process itself needs to be controlled and supervised by public authorities for some reason, for example of particular public concern.

Figure 7: The environmental impact assessment as an institution of environmental risk management

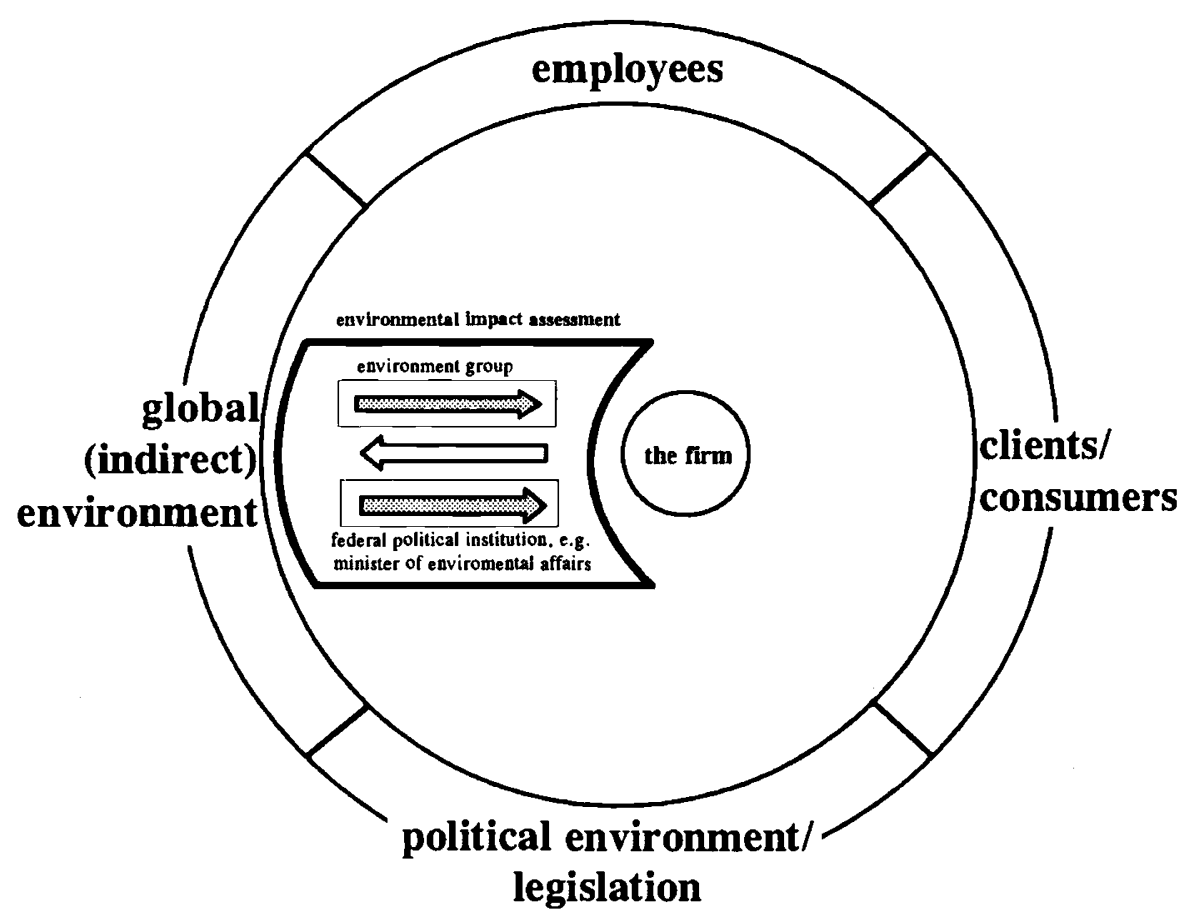

(a) Environmental impact assessment

Since 1990, an environmental impact assessment (EIA) has become obligatory for public and private projects in Germany above a certain size. ${ }^{40}$ This roughly reflects the

${ }^{40}$ For the EIA in general see Häring, S; Nobel, W. (1995); especially as an instrument of risk management see Weale, A. (1992), pp. 35f. 
situation in other European countries as EIA was built in to a Directive of the Council of the European Communities in 1985. In the United States, EIAs have also been practised for some time.

An EIA is organized, for example, when a firm or a public institution plans to build a new plant, major new roads or a new production facility which might have substantial effect on the environment. The EIA is organized and carried out by neutral technological advisors such as the TÜV (Technischer Überwachungs-Verein) in Germany. The technique entails the estimation and evaluation of the environmental quality of the proposal by a neutral party with no commercial or other interest in the project. Members of the public who are directly affected by the project, environmental groups and the company making the proposal are consulted as part of the assessment (Figure 7).

The risk-reducing function of the EIA is a double one. On the one hand, the firm and the neutral authorities carrying out the assessment can explain to the public the objective risks (objective potential emissions) of the project as well as how these might be reduced or contained. This will act to reduce the perceived potential emission of the firm. On the other hand, EIAs reduce the environmental, and especially the economic risk for the company or public body involved, because relevant members of the public and environmental groups are able to articulate their apprehensions and give indications of the strength of their feelings and opposition to the proposal. In this way, the reaction of the stakeholders becomes calculable and the uncertainty surrounding the proposal is reduced. In addition the proposers of the project may be able to reassure their stakeholders on matters causing them particular concern.

\section{(b) Institutions of dispute resolution}

In a similar way to that used during EIAs, the concept of dispute resolution is another institutional vehicle whereby the relations between a company and its external stakeholders on environmental issues, can be regulated. ${ }^{41}$ In this case the process is usually directly managed by the company. This approach has formed part of US practice in some instances.

A group is set up comprising members of governmental institutions, members of the public affected by the project, specialists from industry and environmental groups. The group debates the issues involved and then takes decisions about the project in a structured way. Using this vehicle decisions about the project can be taken and the uncertainty about public reactions to it can be reduced substantially; against this must be set the possibility that the decision made by the group may be far from that which the company had in mind at the outset. However, for a private company, it may well be better to have a decision arrived at through debate with their stakeholders, and therefore accepted by them, than to embark on major undertakings without this «legitimacy». This type of process does bring with it the danger that different parties may not feel committed to the outcome and still oppose the project and, of course, that the opinions on which the decision is based may change over time.

${ }^{41}$ See Weale, A. (1992), pp. 36f. and Jungermann, H.; Rohrmann, B; Wiedemann, P.M. (1990). 


\section{(c) Insurance models}

Another set of institutions which manage the risk and mediate between the firm and its stakeholder groups are insurance companies. If there is an emission insurance companies take over the economic consequences for the firm. Thus, these institutions reduce environmental risk by reducing the consequent economic risk. There may be a danger in this approach that the company, having insured itself against environmental damage, may no longer feel motivated to reduce that risk through its own activities and in this sense, insurance might work as an incentive to pollute the environment. This kind of moral hazard has been met by insurance businesses in the form of contracts which stipulate quite clearly the measures and precautions which they expect the firm to take.

However very few insurance contracts agreed today cover environmental risks partly because of the nature of these risks and insurance contracts in practice only have a rather limited application in environmental risk management. ${ }^{42}$ In the recent past, in contrast, insurance contracts giving more general cover which has been taken to include environmental liabilities, have caused parts of the industry to suffer very large losses. The most notable instance of this has been in the Lloyds market in London which has been hit severely by environmental liabilities from the USA.

This is a difficult subject to address in detail as it is very dependant on national conditions and legislation. In addition, many insurance companies do not only offer insurance per se but also a great number of other consultancy services in the field of risk management thereby helping reduce potential emissions in the sense of section 6.1.

\section{Conclusion}

Environmental risks have to be regarded as one of the most serious challenges for management in business enterprises in the nineties. In part these risks must be addressed through traditional management tools. This is mainly the case with what has been termed «environmental risk» in this paper. However, it has been shown that the structure of environmental risk is unique, especially when the consequent «economic risk» is included. Therefore, management of environmental risk requires a rethinking of relationships with all relevant social groups and institutions which are involved in dealing with environmental problems. Apart from this rethink, many of the tools familiar to the company in the field of marketing will be helpful in environmental risk management. The theoretical framework of institutional economics will serve as a valuable approach in helping firms to organise relationships with those of their stakeholders who are concerned with environmental risk.

${ }^{42}$ For details see Feess-Dörr, E.; Prätorius, G.; Steger, U. (1992), pp. 107-117 and Endres, A.; Rehbinder, E.; Schwarze, R. (1992), pp. 81-119, as well as Nickel, F.G.; Teufl, M. (1993), Schmikowski, P. (1994), and Schmidt, K. (1994). 


\section{REFERENCES}

BALDERJAHN, I. and MENNICKEN, C., (1995) 'Risikomanagement aus verhaltenswissenschaftlicher Sicht', UmweltWirtschafts Forum, Vol. 3, No. 2, pp. 6-11.

BECK, U., (1992a) The Risk Society. Towards a New Modernity, Routledge: London (Originally published as: Beck, U., (1986) Die Risikogesellschaft - Auf dem Weg in eine andere Moderne, Suhrkamp: Frankfurt/Main).

BECK, U., (1992b) 'From Industrial Society to Risk Society: Questions of Survival, Social Structure and Ecological Enlightenment', Theory, Culture \& Society, Vol. 9, pp. 97-123.

BODE, T., (1992) Zur Strategie von Umweltinitiativen, in Steger, U. (ed.) Handbuch des Umweltmanagements, Beck: München, pp. 207-216.

BURGEMEISTER, J. and WEBER, M., (1993) 'Risiko und Akzeptanz von Industrieansiedlungen', Zeitschrift für Betriebswirtschaft, Vol. 63, pp. 147-169.

DYLLICK, T., (1992) Management der Umweltbeziehungen - Öfentliche Auseinandersetzungen als Herausforderung, Gabler: Wiesbaden.

ELSNER, W., (1987) 'Institutionen und ökonomische Institutionentheorie', Wirtschaftswissenschaftliches Studium, Vol. 16, pp. 5-14.

ENDRES, A.; REHBINDER, E.; SCHWARZE, R., (1992) Haftung und Versicherung für Umweltschäden aus ökonomischer und juristischer Sicht, Springer: Berlin et al.

FEES-DÖRR, E.; PRÄTORIUS, G.; STEGER, U., (1992) Umwelthaftungsrecht, 2nd edition, Gabler: Wiesbaden.

FREEMAN, E.R., (1984) Strategic Management: A Stakeholder Approach, Pitman Publishing: Marshfield/Mass.

GASSER, V., (1992) Risk-Management - Unverzichtbar zur Vermeidung von Umweltrisiken, in Lücke, W. and Schulz, K. (eds.) Umweltschutz und Investitionen, Gabler: Wiesbaden, pp. 107-125.

GETHMANN, C.F., (1992) Das Setzen von Umweltstandards als Ausdruck gesellschaftlicher Risikogestaltung, in Wagner, G.R. (ed.) Okonomische Risiken und Umweltschutz, Vahlen: München, pp. 11-26.

HALLER, M., (1991) Risikomanagement - zwischen Risikobeherrschung und Risiko-Dialog, in Organisationsforum Wirtschaftskongress e.V. (ed.) Umweltmanagement zwischen Ökologie und Ökonomie, Gabler: Wiesbaden, pp. 167-220.

HAMMANN, P., (1992) Die öffentliche Akzeptanz innovativer Umweltschutztechnik als Problem der unternehmerischen Risikopolitik, in Wagner, G.R. (ed.) Ökonomische Risiken und Umweltschutz, Vahlen: München, pp. 129-142.

HAMMANN, P. (1995), Umweltakzeptanz, in Junkernheinrich, M. Klemmer, P. and Wagner, G.R. (eds.) Handbuch zur Umweltökonomie, Analytica: Berlin, pp. 256-262.

HÄRING, S. and NOBEL, W., (1995) Umweltverträglichkeitsprüfung, , in Döttinger, K. Roth, K. and Lutz, U. (eds.) Betriebliches Umweltmanagement, Chapter 04.02, Part 7, pp.1-28, Springer: Berlin et al.

JÄNICKE, M., (1995) Akteure der Umweltpolitik, in Junkernheinrich, M. Klemmer, P. and Wagner, G.R. (eds.) Handbuch zur Umweltökonomie, Analytica: Berlin, pp. 11-15.

JANZEN, H. and MATTEN, D., (1995) Umweltorientierte Planungsinstrumente, in Döttinger, K. Roth, K. and Lutz, U. (eds.) Betriebliches Umweltmanagement, Chapter 02.04, pp.1-29, Springer: Berlin et al.

JANZEN, H., (1995) Risikopolitik und Umweltschutz, in Junkernheinrich, M. Klemmer, P. and Wagner, G.R. (eds.) Handbuch zur Umweltökonomie, Analytica: Berlin, pp. 348-356. 
JANZEN, H., (1996) Ökologisches Controlling im Dienste von Umwelt- und Risikomanagement, Schäffer-Poeschel: Stuttgart.

JUNG, M. and SPREMANN, K., (1989) 'Transaktionsrisiken', Zeitschrift für Betriebswirtschaft, Vol. 59, pp. 94-112.

JUNGERMANN, H. ROHRMANN, B. and WIEDEMANN, P.M. (eds.), (1990) Risiko-Konzepte Risiko-Konflikte Risiko-Kommunikation, Forschungszentrum Jülich: Jülich.

KAAS, K.P., (1992) Marketing und neue Institutionenlehre, Arbeitspapier No. 1 aus dem Forschungsprojekt Marketing und neue Institutionenlehre, University of Frankfurt: Frankfurt am Main.

KAAS, K.P., (1993) Informationsprobleme auf Märkten für umweltfreundliche Produkte, in Wagner, G.R. (ed.) Betriebswirtschaft und Umweltschutz, Schäffer-Poeschel: Stuttgart, pp. 29-43.

KAAS, K.P., (1994) Marketing im Spannungsfeld zwischen umweltorientiertem Wertewandel und Konsumentenverhalten, in Schmalenbach-Gesellschaft (ed.) Unternehmensführung und externe Rahmenbedingungen, Schäffer-Poeschel: Stuttgart, pp. 93-112.

KARL, H., (1995) Umweltrisiken, in Junkernheinrich, M. Klemmer, P. and Wagner, G.R. (eds.) Handbuch zur Umweltökonomie, Analytica: Berlin, pp. 327-332.

KASPERSON, R.E. and STALLEN, P.J.M. (eds.), (1991) Conmmunicating Risk to the Public International Perspective, Kluwer Academic Publishers: Dordrecht et al.

KEPPE, H.J. and WEBER, M., (1993) 'Risikoanalyse bei partieller Wahrscheinlichkeitsinformation', Die Betriebswirtschaft, Vol. 53, pp. 49-56.

KIRCHGEORG, M., (1993) ‘Risiko-Kommunikation', Die Betriebswirtschaft, Vol. 53, pp. 127-128.

KISTNER, K.-P. and STEVEN, M., (1991) 'Management ökologischer Risiken in der Produktionsplanung', Zeitschrift für Betriebswirtschaft, Vol. 61, pp. 1307-1336.

KLATTENHOFF, H., (1994) Soziologie und Umwelt(zerstörung). Eine Annäherung diskutert am Beispiel des zusätzlichen Treibhauseffekts und den Konzepten von Ulrich Beck, Niklas Luhmann und Rolf Peter Sieferle, SOKOOP: Duisburg.

KLOEPFER, M., (1993) 'Betrieblicher Umweltschutz als Rechtsproblem', Der Betrieb, Vol. 46, pp. 1125-1131.

KNÖDGEN, G., (1992) Die Rolle von Behörden und Kommunen, in Steger, U. (ed.) Handbuch des Umweltmanagements, Beck: München, pp. 165-182.

KRIMSKY, S. and GOLDING, D. (eds.), (1992) Social Theories of Risk, Praeger Publishers: Westport/Connecticut, London.

MATTEN, D., (1994) Das Management ökologischer Unternehmensrisiken als Konzeption einer nachhaltigen Unternehmensentwicklung, in Studenteninitiative Wirtschaft und Umwelt e.V. (ed.) Im Namen der Zukunft - Politische Wege in die Nachhaltigkeit, Druckwerkstatt: Münster, pp. 195-243.

MATTEN, D., (1995a) 'Strategy follows Structure: Environmental Risk Management in Commercial Enterprises', Business Strategy and the Environment, Vol. 4, pp. 107-116.

MATTEN, D., (1995b) Unternehmensplanung und Umwelt, in Junkernheinrich, M. Klemmer, P. and Wagner, G.R. (eds.) Handbuch zur Umweltökonomie, Analytica: Berlin, pp. 338-344.

MEFFERT, H. and KIRCHGEORG, M., (1993) Marktorientiertes Umweltmanagement, 2nd ed., Schäffer-Poeschel: Stuttgart.

MULHALL, D., (1992) Environmental Management: The Relationship between Pressure Groups and Industry - A Radical Redesign, in Koechlin, D.; Muller, K. (eds.): Green Business Opportunities The Profit Potential, Pitman Publishing: London 1992, pp. 187-203.

NICKEL, F. and TEUFL, M., (1993) 'Der Umweltschaden in Betriebs-Haftpflichtversicherung', Versicherungswirtschaft, Vol. 48, pp. 1126-1132. 
NOUR ELDIN, H.(ed.), (1989) Hoechst-Gespräch 1988. Das Risiko und seine Akzeptanz, Schütze: Bonn.

RENN, O. and KALS, J., (1990) Technische Risikoanalyse und unternehmerisches Handeln, in Schüz, M. (ed.) Risiko und Wagnis, Vol. 1, Neske: Pfullingen, pp. 60-80.

RENN, O. WEBLER T. and WIEDEMANN, P.M. (eds.), (1995) Fairness and Competence in Citizen Participation, Kluwer: Dordrecht et al.

ROHRMANN, B., (1990) Akteure der Risiko-Kommunikation, in Jungermann, H. Rohrmann, B. and Wiedemann, P.M. (eds.) Risiko-Konzepte Risiko-Konflikte Risiko-Kommunikation, Forschungszentrum Jülich: Jülich, pp. 329-343.

SCHMIDT, K., (1994) Haftungsrisiken für Umweltschutz und technische Sicherheit, in Breuer, R. Kloepfer, M. Marburger, P. and Schröder, M. (eds.) Umweltschutz und technische Sicherheit im Unternehmen, v. Decker: Heidelberg, pp. 69-92.

SCHIMIKOWSKI, P., (1994) 'Ausschluß des Umwelthaftpflichtrisikos aus der gewerblichen und industriellen Haftpflichtversicherung', Versicherungswirtschaft, Vol. 49, pp. 748-752.

SHRIVASTAVA, P., (1995) 'Ecocentric Management for a Risk Society', Academy of Management Review, Vol. 20, No. 1, pp. 118-137.

SPREMANN, K., (1990) ‘Asymmetrische Information’, Zeitschrift für Betriebswirtschaft, Vol. 60, pp. 561-586.

STEGER, U. and ANTES, R., (1991) Unternehmensstrategie und Risiko-Management, in Steger, U. (ed.) Umwelt-Auditing. Ein neues Instrument der Risikovorsorge, FAZ/Gabler: Frankfurt/Main.

STEINMANN, H. and ZERFASS, A., (1993) Privates Unternehmertum und öffentliches Interesse, in Wagner, G.R. (ed.) Betriebswirtschaft und Umweltschutz, Schäffer-Poeschel: Stuttgart, pp. 3-26.

STEINMANN, H. and ZERFASS, A., (1995) Management der integrierten Unternehmenskommunikation, in Ahrens, $\mathrm{R}$. Scherer, $\mathrm{H}$. and Zerfass, A. (eds.) Integriertes Kommunikationsmanagement, FAZ: Frankfurt/Main, pp. 11-50.

THE ROYAL SOCIETY (ed.), (1992) Risk: Analysis, Perception and Management, Amber Printwork: London.

WAGNER, G.R., (1991) Entrepreneurship and Innovation from an Environmental Risk Perspective, in Roberts, L. and Weale, A. (eds.) Innovation and Environmental Risk, Belhaven: London, New York, pp. 138-148.

WAGNER, G.R. (ed.), (1992) Ökonomische Risiken und Umweltschutz, Vahlen: München.

WAGNER, G.R. and MATTEN, D., (1992) 'Die Erstellung innovativer technischer Grossysteme im Spannungsfeld ökonomischer und ökologischer Risiken - diskutiert am Fall Transrapid', Die Betriebswirtschaft, Vol. 52, pp. 359-383.

WAGNER, G.R. and MATTEN, D., (1995) 'Betriebswirtschaftliche Konsequenzen des Kreislaufwirtschaftsgesetzes', Zeitschrift für angewandte Umweltforschung, Vol. 8, pp. 45-57.

WEALE, A., (1992) Umweltbezogene Risikosteuerung durch transaktionskostenorientierte Institutionen, in Wagner, G.R. (ed.) Ökonomische Risiken und Umweltschutz, Vahlen: München, pp. 27-45.

WIEDEMANN, P.M., (1990) Strategien der Risiko-Kommunikation und ihre Probleme, in Jungermann, H. Rohrmann, B. and Wiedemann, P.M. (eds.) Risiko-Konzepte Risiko-Konflikte Risiko-Kommunikation, Forschungszentrum Jülich: Jülich, pp. 345-367.

WILLIAMSON, O.E., (1990) Die ökonomischen Institutionen des Kapitalismus, J.C.B. Mohr (Paul Siebeck): Tübingen.

WIMMER, F., (1993) Empirische Einsichten in das Umwelthewußtsein und Umweltverhalten der Konsumenten, in Wagner, G.R. (ed.) Betriebswirtschaft und Umweltschutz, Schäffer-Poeschel: Stuttgart, pp. 44-78. 